\title{
Improving the Competitiveness of Poultry Farms in the Krasnoyarsk Region of Russia
}

\author{
Alena Rozhkova ${ }^{1, *}$, and Elina Stepanova ${ }^{1}$ \\ ${ }^{1}$ Krasnoyarsk State Agrarian University, Krasnoyarsk, Russia
}

\begin{abstract}
Poultry farming is one of the key branches of agriculture. Every year, the demand for dietary products of poultry farms increases, both consumers and producers are interested in the development of agricultural enterprises that supply poultry meat and eggs. In the market of the region there are a large number of poultry farms that supply meat products. The competitive environment of modern poultry farms is characterized by acute competition for the consumer. The solution to the problem of increasing the competitiveness of enterprises involves the development of measures to achieve and maintain competitive advantages in this market. The article presents the analysis results of the competitiveness for key suppliers of poultry meat and eggs in the regional market of the Krasnoyarsk region. The criteria of poultry farms competitiveness in the region are defined. Expert assessments of competitors based on the "4P"concept are compiled. Based on the results of the analysis, a competitiveness diagram of the largest regional producers of poultry meat and eggs is compiled. On the basis of the competitiveness polygon, the development directions of competitive advantages of poultry farms in the region are identified. The proposed measures to promote sales in the format of outside trade will lead to changes in the competitiveness polygon of poultry farms. The article presents recommendations for the acquisition and development of stable competitive positions in the regional market of poultry products. The key success factors influencing the competitiveness of poultry farms in the regional poultry meat market are identified, the most important trends in the development of the competitive environment and ways to improve the competitiveness of poultry farms and their adaptation to changing conditions are presented.
\end{abstract}

\section{Introduction}

At the present stage of agricultural development, poultry farming is considered as a rapidly developing industry with a high potential for providing the population with dietary products. Poultry farming is attractive for agricultural enterprises, as they are characterized by rapid reproduction. Thanks to production technologies, scientific achievements and state support, poultry farming is becoming an affordable activity for many agricultural enterprises.

The key task of poultry farms is the breeding of poultry for the purpose of obtaining meat and eggs. Additional products of the poultry industry are fluff, feather and droppings. These types of products are further used as feed, fertilizers; fluff and feather are sold to textile factories. The products of poultry farms are of strategic importance for economic development, as there is an increased demand for the food and confectionery industry, feed production, pharmaceuticals for the production of food additives and vitamins.

In modern economic conditions, enterprises need to be competitive (monitor their strengths and weaknesses) improve, and be better than their competitors in order to survive in the market [1-4]. Now the market has a lot of poultry farms that provide meat products. Enterprises strive for leadership by improving the quality of products, their diversity, promotion, and production technologies.

An important role in the search for ways to improve competitiveness is given to the analysis of competitors [5-8]. With it, develop strategy and tactics to improve competitiveness, settled plans and management decisions, monitor their implementation, increases the ability to assess the current state of the enterprise and to forecast the future, to identify the reserves for increasing production efficiency and enterprises to evaluate the results of the company.

For many centuries, the production and consumption of poultry products were insignificant due to the small number and low productivity of poultry. Until the beginning of the 20th century, poultry products did not enter the world market. But with the transition of poultry farming to an industrial basis, its role in world agriculture has changed radically.

Poultry production has increased significantly over the past 15 years. Chicken production accounts for $70 \%$ of all poultry production (USA, China, Brazil), turkey meat - $10 \%$ (USA, Canada, EU), duck meat - $6 \%$ (Asia). In recent years, the Russian poultry industry has shown steady growth and development of the entire industry as a whole; this makes a significant contribution

\footnotetext{
* Corresponding author: tutor.eng@yandex.ru
} 
to the country's economy, which also indicates good prospects for the future.

Poultry farms in the Russian Federation breed about 17 egg poultry species and 11 meat species. Our own breeding production has appeared and is developing. In the country, the leading species are those bred directly by domestic breeders.

On the territory of Russia, poultry farming is represented by:

- more than 650 industrial organizations

- 425 factories producing egg products

- 130 factories are engaged in broiler breeding

- 50 firms are engaged in the field of breeding production

- 12 farms specialize in raising geese

- 9 farms breed exclusively ducks

- 5 are engaged in turkeys

-3 are engaged in quails.

There are many companies that distribute products throughout Russia, and export goods abroad. For example, the group of agricultural enterprises (GAE) "Resource" is one of the largest agro-industrial companies in Russia and one of the leading producers of chicken meat in the country. The company was established in 2003. The GAE "Resource" unites eight poultry farms located in the south of the country. Their trademarks are: "Blagoyar", "Our bird", "An-Noor" and "URUSSA".

The GAE "Resource" has been actively developing its export business and has been constantly expanding its geographical presence since 2012. The company successfully sells its products in the CIS countries, the Middle East, Africa, Asia and Europe. The list of trade partners includes representatives from more than 40 countries around the world [9-12]. In 2018, the only Russian poultry processing plant specializing in the production of exclusively halal products began operating in the GAE "Resource". In this regard, the Middle East countries were interested in cooperation with the GAE "Resource", because they corresponded to their interests, culture, and so on.

\section{Materials and methods}

The growth in the production of poultry farms leads to increased competition in the market of the poultry industry, so at the current stage of development, poultry farms pay great attention to improving competitiveness. There are various methods of analysing competitiveness: Porter method, SWOT analysis, GAP method, PIMS method, 4P method. Each method of analysis reveals the essence of the competitiveness for the studied object. The object of the presented research is the poultry farm of JSC "Yeniseyagrosoyuz", the largest meat producer in the regional market of the Krasnoyarsk region.

Meat and poultry farming in the Krasnoyarsk region in recent years shows a steady annual increase in production and is the most dynamic branch of the agroindustrial complex of the region.

The market structure can be divided into three groups based on the location of the main market players.
The first group is represented by poultry producers of the Krasnoyarsk region. The second group consists of producers from neighbouring regions. The third group includes "federal" poultry producers. Consider the representatives of the three main groups.

Table 1. Poultry meat market of the Krasnoyarsk region.

\begin{tabular}{|l|l|l|}
\hline $\begin{array}{l}\text { Local } \\
\text { producers }\end{array}$ & $\begin{array}{l}\text { Production of } \\
\text { neighbouring } \\
\text { regions }\end{array}$ & $\begin{array}{l}\text { Federal } \\
\text { producers }\end{array}$ \\
\hline $\begin{array}{l}\text { JSC } \\
\text { "Yeniseyagros } \\
\text { oyuz" }\end{array}$ & $\begin{array}{l}\text { JSC "Barkhatovskaya } \\
\text { Poultry farm" }\end{array}$ & $\begin{array}{l}\text { JSC "Healthy } \\
\text { Farm" }\end{array}$ \\
\hline JSC "Zarya" & JSC "Altai Broiler" & $\begin{array}{l}\text { JSC "Chebarkul } \\
\text { bird" }\end{array}$ \\
\hline & $\begin{array}{l}\text { JSC " Rovensky } \\
\text { broiler" }\end{array}$ & \\
\hline & JSC "Seltorg" & \\
\hline
\end{tabular}

The assessment and analysis of the competitiveness of products is currently being investigated by various market participants: manufacturers, competitors, and investors. In the practical solution for the problems of assessing the competitiveness of products, there is a need to choose certain methods. The choice of methods is a key decision that should satisfy the functional completeness and reliability of the assessment. And the time and cost of determining it are reduced.

Table 2. Analysis of the evaluating each competitor.

\begin{tabular}{|l|l|l|l|}
\hline \multirow{2}{*}{ Title } & \multicolumn{3}{|l|}{$\begin{array}{l}\text { Evaluating the strength of each } \\
\text { competitor }\end{array}$} \\
\cline { 2 - 4 } & Support & $\begin{array}{l}\text { Market } \\
\text { share }\end{array}$ & Conclusion \\
\hline JSC "Zarya" & no & higher & strong \\
\hline $\begin{array}{l}\text { JSC } \\
\text { "Barkhatovskaya } \\
\text { Poultry farm" }\end{array}$ & no & $\begin{array}{l}\text { at the } \\
\text { level }\end{array}$ & weak \\
\hline JSC "Altai Broiler" & no & higher & strong \\
\hline $\begin{array}{l}\text { JSC "Rovensky } \\
\text { broiler" }\end{array}$ & no & $\begin{array}{l}\text { at the } \\
\text { level }\end{array}$ & weak \\
\hline $\begin{array}{l}\text { LLC "Seltorg" } \\
\text { JSC "Healthy Farm }\end{array}$ & no & $\begin{array}{l}\text { at the } \\
\text { level }\end{array}$ & strong \\
\hline " higher & strong \\
\hline $\begin{array}{l}\text { JSC " Chebarkul } \\
\text { bird» }\end{array}$ & no & $\begin{array}{l}\text { at the } \\
\text { level }\end{array}$ & weak \\
\hline
\end{tabular}

Strong competitors should be considered as a threat to the company. Against these players, the right defense strategies are necessary, aimed at retaining and increasing the loyalty of current customers. Weak competitors are sources of business growth. Consumers of these players are the most attractive potential customers [13-16]. The principle of working with weak competitors is: programs and actions aimed at switching customers.

The largest suppliers of poultry products in the region's market: poultry farms of JSC "Yeniseyagrosoyuz", JSC "Barkhatovskaya Poultry farm", JSC "Altai broiler". JSC "Barkhatovskaya Poultry farm" is a major producer of eggs, but in recent years the company has started to supply chicken meat. The results 
of the competitor analysis based on the "4P" concept are presented in Table 3.

Table 3. Competitor analysis based on the "4P" concept.

\begin{tabular}{|c|c|c|c|c|}
\hline $\begin{array}{l}\text { Factors of } \\
\text { competitiven } \\
\text { ess }\end{array}$ & $\begin{array}{l}\text { JSC } \\
\text { "Yenis } \\
\text { eyagro } \\
\text { soyuz" }\end{array}$ & $\begin{array}{l}\text { JSC } \\
\text { "Barkhat } \\
\text { ovskaya } \\
\text { Poultry } \\
\text { farm" }\end{array}$ & $\begin{array}{l}\text { JSC } \\
\text { "Altai } \\
\text { broiler" }\end{array}$ & $\begin{array}{l}\text { JSC } \\
\text { "Selto } \\
\text { rg" }\end{array}$ \\
\hline \multicolumn{5}{|l|}{ 1. Product } \\
\hline Appearance & 4 & 3 & 5 & 5 \\
\hline Assortment & 4 & 3 & 5 & 4 \\
\hline Taste & 5 & 5 & 5 & 5 \\
\hline The amount & 13 & 11 & 15 & 14 \\
\hline \multicolumn{5}{|l|}{ 2. Price } \\
\hline Wholesale & 4 & 5 & 5 & 4 \\
\hline Retail & 4 & 3 & 4 & 3 \\
\hline $\begin{array}{ll}\text { Types of } \\
\text { discounts }\end{array}$ & 3 & 1 & 3 & 4 \\
\hline The amount & 11 & 9 & 12 & 11 \\
\hline \multicolumn{5}{|c|}{ 3. Sales channels } \\
\hline $\begin{array}{l}\text { Degree of } \\
\text { market } \\
\text { coverage }\end{array}$ & 3 & 4 & 4 & 5 \\
\hline Sales regions & 4 & 4 & 5 & 5 \\
\hline $\begin{array}{l}\text { Efficiency of } \\
\text { the sales } \\
\text { network }\end{array}$ & 4 & 4 & 4 & 5 \\
\hline The amount & 11 & 12 & 13 & 15 \\
\hline \multicolumn{5}{|l|}{ 4. Promotion } \\
\hline $\begin{array}{l}\text { The } \\
\text { advertising } \\
\text { channels }\end{array}$ & 2 & 5 & 5 & 4 \\
\hline $\begin{array}{l}\text { The } \\
\text { advertising } \\
\text { budget }\end{array}$ & 3 & 5 & 4 & 3 \\
\hline $\begin{array}{l}\text { Communicati } \\
\text { on with the } \\
\text { public }\end{array}$ & 2 & 4 & 3 & 4 \\
\hline The amount & 7 & 14 & 12 & 11 \\
\hline
\end{tabular}

Expert assessments of competitors are compiled according to such criteria as price, assortment, sales volume, promotion, recognition, and outside trade.

Table 4. Expert assessments of the competitiveness for poultry farms in the region.

\begin{tabular}{|l|l|l|l|l|}
\hline Criteria & $\begin{array}{l}\text { JSC } \\
\text { "Yenis } \\
\text { eyagros } \\
\text { oyuz" }\end{array}$ & $\begin{array}{l}\text { JSC } \\
\text { "Barkhato } \\
\text { vskaya } \\
\text { Poultry } \\
\text { farm" }\end{array}$ & $\begin{array}{l}\text { JSC } \\
\text { "Altai } \\
\text { broiler } \\
"\end{array}$ & $\begin{array}{l}\text { JSC } \\
\text { "Seltor } \\
\text { g" }\end{array}$ \\
\hline Price & 9 & 8 & 6 & 7 \\
\hline Assortment & 8 & 4 & 9 & 8 \\
\hline $\begin{array}{l}\text { Sales } \\
\text { volume }\end{array}$ & 7 & 5 & 9 & 7 \\
\hline Promotion & 4 & 5 & 8 & 7 \\
\hline Recognition & 6 & 4 & 8 & 6 \\
\hline $\begin{array}{l}\text { Outside } \\
\text { trade }\end{array}$ & 0 & 6 & 0 & 0 \\
\hline
\end{tabular}

A diagram of the competitiveness of JSC "Yeniseyagrosoyuz" to other competitors on the basis of expert estimates was made.

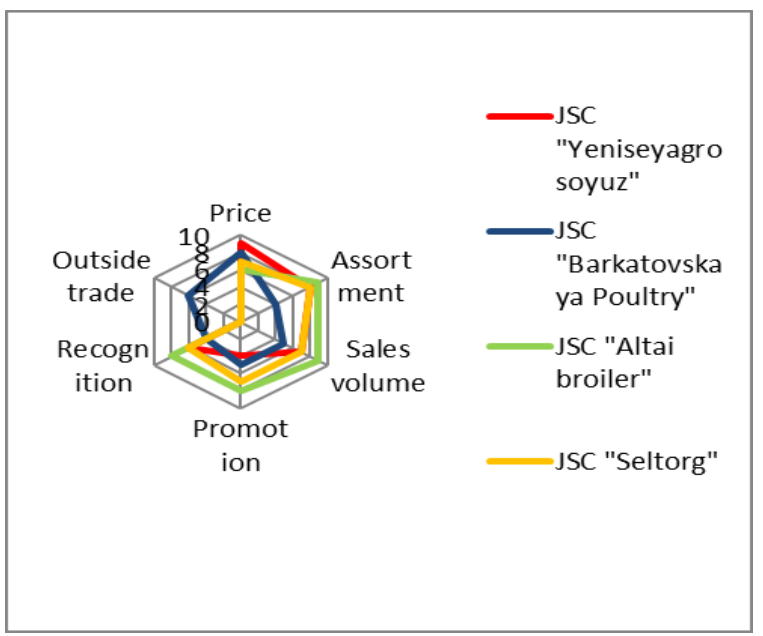

Fig. 1. The competitiveness polygon.

From this diagram, it follows that the recognition of the JSC "Barkhatovskaya Poultry farm" is lower, since they have begun to supply chicken meat to stores recently. In the "Outside trade" parameter, JSC "Barkhatovskaya Poultry farm" has the only high indicator, the organization has recently begun to promote its products through trading in vans, in connection with which it increased its awareness and sales volume. Direct sales channel contributes to the promotion and sale of products on the market [17-21].

\section{Results}

The organization of a direct sales channel is proposed to be implemented through the introduction of mobile trade (mobile car counters) in Krasnoyarsk. The main advantage of this business type is the creation of conditions for the products sale without intermediaries and free movement around the city. The largest regional poultry meat producer JSC "Yeniseyagrosoyuz" was selected as an approbation.

Table 5. Characteristics of marketing channels JSC "Yeniseyagrosoyuz" and JSC "Barkhatovskaya Poultry farm".

\begin{tabular}{|l|l|l|}
\hline $\begin{array}{l}\text { Sales } \\
\text { channels }\end{array}$ & $\begin{array}{l}\text { JSC } \\
\text { "Yeniseyagrosoyuz" }\end{array}$ & $\begin{array}{l}\text { JSC } \\
\text { "Barkhatovskaya } \\
\text { Poultry farm" }\end{array}$ \\
\hline Direct sale & $\begin{array}{l}\text { Fairs, sales by } \\
\text { employees of the } \\
\text { enterprise }\end{array}$ & $\begin{array}{l}\text { Mobile car counters } \\
\text { for the sale of } \\
\text { products, fairs, sales } \\
\text { to employees of the } \\
\text { enterprise }\end{array}$ \\
\hline Distributors & $\begin{array}{l}\text { Large wholesale } \\
\text { organizations, } \\
\text { including individual } \\
\text { entrepreneurs, retail } \\
\text { chains }\end{array}$ & $\begin{array}{l}\text { Large wholesale } \\
\text { organizations, } \\
\text { including individual } \\
\text { entrepreneurs, retail } \\
\text { chains }\end{array}$ \\
\hline $\begin{array}{l}\text { State and } \\
\text { municipal } \\
\text { institutions }\end{array}$ & $\begin{array}{l}\text { Kindergartens and } \\
\text { schools }\end{array}$ & $\begin{array}{l}\text { Kindergartens and } \\
\text { schools }\end{array}$ \\
\hline
\end{tabular}

The event is introduced to improve competitiveness by expanding sales channels on the example of the introduction of a retail store on wheels. 
Outside trade has been around for a long time and is now gaining momentum with its popularity and practicality. Many companies use this trade in order to increase sales, increase the popularity of products and increase the competitiveness of products. Therefore, it is recommended to propose this event to improve the competitiveness of the studied enterprise, JSC "Yeniseyagrosoyuz".

JSC "Yeniseyagrosoyuz" is a local enterprise, it distributes products only in the Krasnoyarsk region, in this regard, it's better for this enterprise to expand its territorial supply. It's better to start with the nearest districts, regions, and then cooperate with foreign companies and enter the world market [22-26]. It's also better to follow the interests of other countries and peoples to meet their needs and desires with products and cooperate with them.

Table 6. Advantages and disadvantages of outside trade.

\begin{tabular}{|l|l|}
\hline \multicolumn{1}{|c|}{ Advantages } & \multicolumn{1}{c|}{ Disadvantages } \\
\hline Small risks & $\begin{array}{l}\text { The problem with the } \\
\text { machine }\end{array}$ \\
\hline $\begin{array}{l}\text { Low costs for the implementation } \\
\text { of the business plan }\end{array}$ & $\begin{array}{l}\text { Emergency situations } \\
\text { when traveling }\end{array}$ \\
\hline $\begin{array}{l}\text { The ability to change the place of } \\
\text { sale of the product, taking into } \\
\text { account the needs of residents }\end{array}$ & \\
\hline Fast payback period & \\
\hline $\begin{array}{l}\text { Small list of documents for } \\
\text { business resolution }\end{array}$ & \\
\hline Saving on advertising & \\
\hline
\end{tabular}

It should be noted that there are few obstacles to the implementation of the business plan. This proposal for improving the competitiveness of JSC "Yeniseyagrosoyuz" will be beneficial to implement.

It is advisable to choose the location of a retail outlet according to one of the main criteria - the maximum crowd of people and the maximum possibility.

The following options for the location of a retail outlet are offered:

- in a residential area with a large number of multistorey buildings;

- in a new residential district under construction;

- location on the site of a transport interchange with bus stops;

- close to educational institutions.

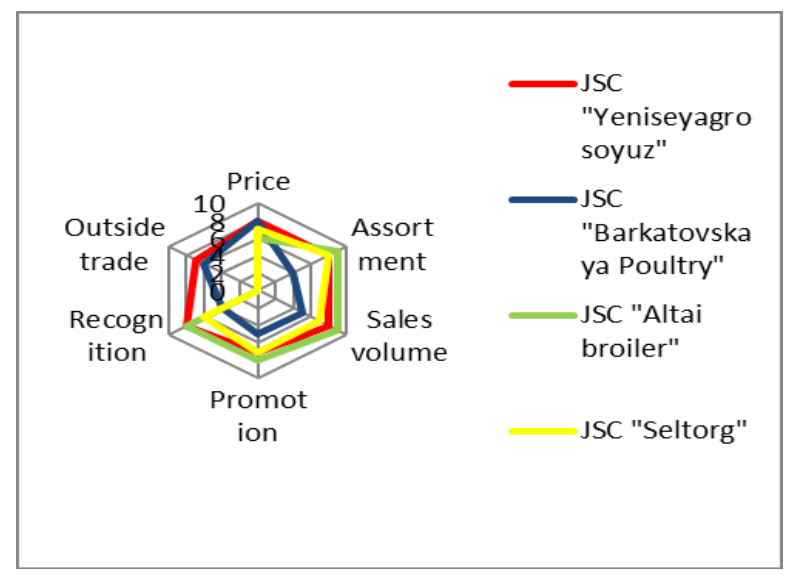

Fig. 2. Changes in the competitiveness polygon after the introduction of outside trade.

After the introduction of outside trade, a significant change in the diagram of the competitiveness JSC "Yeniseyagrosoyuz" is marked. This offer helps to increase the awareness and sales volume of the company's products. Consumers who did not buy meat of JSC "Yeniseyagrosoyuz" have the same opportunity to see the products of the enterprise simply by looking at the mobile car counters. This event is aimed at stimulating sales: customers have a desire to simply try the products and subsequently increase confidence in them.

\section{Conclusion}

Solving the problem of increasing the competitiveness of domestic poultry farming in modern conditions will strengthen the position of the industry in Russian and foreign markets. In order to gain and develop a stable competitive position in the meat market, agricultural enterprises must consider the key success factors in the competitive markets of the agro-industrial complex, identify the most important trends in the development of the competitive environment and adequately respond to changing conditions. Increased competition in the market for the production and sale of agricultural products encourages poultry farms to find ways to increase competitiveness by:

- ensuring the reliability and efficiency of the enterprise;

- achieving high quality in customer service;

- introduction and development of information and innovative technologies as a way to achieve competitive advantages.

\section{References}

1. O.I. Antamoshkina, O.V. Zinina, A.O. Stupin, Method of forming of the program of issue of competitive products of machine-building industry, IOP Conference Series: Materials Science and Engineering, 862 (4), 042029 (2020)

2. O.A. Brilevsky, Commodity science of food products (Belarusian state economic university, 2006) 
3. O. Zinina, J. Olentsova, Evaluating the Effectiveness of Company Development in Processing Industry, E3S Web of Conferences, 161, 01074 (2020)

4. N.A. Dalisova, A.V. Sharopatova, M.V. Karaseva, Value and role of the strategic management in the development of agricultural enterprises, IOP Conference Series: Earth and Environmental Science, 548 (2), 022102 (2020)

5. P. Hazell, C. Poulton, S. Wiggins, A. Dorward, The Future of Small Farms: Trajectories and Policy Priorities, World Development, 38 (10), 1349-1361 (2010) DOI: 10.1016/j.worlddev.2009.06.012

6. O. Nezamova, J. Olentsova, Monitoring Consumer Behaviour in the Food Market in the Krasnoyarsk Region of Russia, E3S Web of Conferences, 161, 01080 (2020)

7. Y. Koloskova, N. Dalisova, Z. Shaporova, The role of human capital in the development of agribusiness, IOP Conference Series: Earth and Environmental Science, 315 (2), 022103 (2019)

8. J.D. van der Ploeg, J. Ye, L. Pan, Peasants, time and the land: The social organization of farming in China, Journal of Rural Studies, 36, 172-181 (2014) DOI: 10.1016/j.jrurstud.2014.07.002

9. O.V. Zinina, N.A. Dalisova, J.A. Olentsova, Dynamics and structure of manufacturing bread and bakery products in the Krasnoyarsk region, IOP Conference Series: Earth and Environmental Science, 548 (2), 022028 (2020)

10. C. Potter, M. Lobley, Helping small farms and keeping Europe beautiful: A critical review of the environmental case for supporting the small familyfarm, Land Use Policy, 10 (4), 267-279 (1993) DOI: 10.1016/0264-8377(93)90037-B

11. O.I. Antamoshkina, O.V. Zinina, A methodology for assessing the prospects of modifying business strategy of an enterprise in the external environment, IOP Conference Series: Materials Science and Engineering, 537 (4), 042023 (2019)

12. A.V. Sharopatova, N.I. Pyzhikova, J.A. Olentsova, The current situation of the poultry industry and the formation of a strategy for its sustainable development in the region, IOP Conference Series: Earth and Environmental Science, 421 (2), 022061 (2020)

13. C. Poulton, A. Dorward, J. Kydd, The Future of Small Farms: New Directions for Services, Institutions, and Intermediation, World Development, 38 (10), 1413-1428 (2010) DOI: 10.1016/j.worlddev.2009.06.009

14. N.A. Dalisova, I.I. Grishina, Personnel training as a factor in the formation of the export potential of the agro-industrial complex of the region, IOP Conference Series: Earth and Environmental Science, 315 (2), 022072 (2019)

15. O.I. Antamoshkina, O.V. Zinina, J.A. Olentsova, Methodology of building a master's individual educational route for effective development of professional competencies, Journal of Physics: Conference Series, 1691 (1), 012207 (2020)
16. S. Wiggins, J. Kirsten, L. Llambí, The Future of Small Farms. World Development, 38 (10), 1341$1348 \quad(2020) \quad$ DOI: 10.1016/j.worlddev.2009.06.013

17. A. Olga, Z. Olga, O. Julia, The formation of the alternative list in the output of competitive ecological products, International Multidisciplinary Scientific GeoConference Surveying Geology and Mining Ecology Management, SGEM, 18 (5.3), 863-870 (2018)

18. O.V. Zinina, N.A. Dalisova, N.I. Pyzhikova, J.A. Olentsova, Development prospects of the Krasnoyarsk region agroindustrial complex in the export conditions, IOP Conference Series: Earth and Environmental Science, 315 (2), 022068 (2019)

19. M.A. Yanova, E.N. Oleynikova, A.V. Sharopatova, J.A. Olentsova, Increasing economic efficiency of flour production from grain of the main cereal crops by extrusion method, IOP Conference Series: Earth and Environmental Science, 315 (2), 022024 (2019)

20. N.A. Dalisova, M.V. Karaseva, State support for export of agro-industrial complex products of the Krasnoyarsk Territory, IOP Conference Series: Earth and Environmental Science, 548 (2), $022093(2020)$

21. S.S. Yuferev, M.I. Lesovskaya, Yu.A. Olentsova, Optimal weight and power parameters of crawler tractors to reduce pressure on the soil, IOP Conference Series: Earth and Environmental Science, 315 (5), 052009 (2019)

22. O.A. Nezamova, J.A. Olentsova, Adaptation problems of the food market to modern conditions, IOP Conference Series: Earth and Environmental Science, 548 (8), 082023 (2020)

23. O.V. Zinina, O.I. Antamoshkina, J.A. Olentsova, Analysis of innovative activity in the agroindustrial complex of the Krasnoyarsk region, IOP Conference Series: Earth and Environmental Science, 548 (2), 022033 (2020)

24. Y.V. Smolnikova, M.A. Yanova, V.L.Bopp, J.A. Olentsova, Assessment of the seed safety indicators from oilseed cruciferous crops in the organization of complex processing technology, IOP Conference Series: Earth and Environmental Science, 315 (2), 022061 (2019)

25. O.V. Zinina, N.A. Dalisova, M.V. Karaseva, B2B sphere as an element of the exports potential development in the agricultural sector of the region, IOP Conference Series: Earth and Environmental Science, 421 (2), 022012 (2020)

26. A. Rozhkova, J. Olentsova, Development of New Technological Solutions for the Dairy Industry, E3S Web of Conferences, 161, 01086 (2020). 